\title{
Kamu Sektöründe Çalışan Kadınların Çalışma Hayatlarının Aile Üzerindeki Etkileri
}

\section{Impacts of Professional Life of Women Working in Public Sector on Their Families}

\author{
Adem Palabıy1k ${ }^{\text {a,* }}$ \\ ${ }^{a}$ Dr. Öğr. Üyesi, Muș Alparslan Üniversitesi, Fen Edebiyat Fakültesi, Sosyoloji Bölümü, 49250, Muş/Türkiye. \\ ORCID: 0000-0002-9209-9313
}

\section{MAKALE BİLGİSI}

\section{Makale Geçmişi:}

Başvuru tarihi: 16 Şubat 2018

Düzeltme tarihi: 02 Mart 2018

Kabul tarihi: 08 Mart 2018

\section{Anahtar Kelimeler:}

Kadin

Kamusal Alan

Aile

Annelik

Anket

\section{ARTICLE INFO}

\section{Article history:}

Received 16 February 2018

Received in revised form 02 March 2018

Accepted 08 March 2018

\section{Keywords:}

Women

Public Domain

Family

Motherhood

Survey
ÖZ

$\mathrm{Bu}$ araştırmanın konusu, kamu sektöründe çalışan kadının çalışma hayatının aile üzerindeki etkilerinden oluşmaktadır. Öncelikle aileyi tanımlayıp özellikleri ve fonksiyonlarını belirterek, değişen aile yapısı tanımlanmıştır. Aile yapısının değişimini etkileyen faktörleri ve bunların ortaya çıkardığı sonuçlarla beraber ailenin görevlerindeki değişim irdelenmiştir. Kadının değişen konumunu ve iş hayatına girişinin tarihçesini açılayarak çalışmanın bel kemiği olan kamu sektöründe kadının çalışmasına işaret ederek, kadının bu çalışma hayatında karşılaştığı sorunlara ve çalışma yaşamındaki kadının aile içinde üstlendiği görevlere yer verilmiştir. Ayrıca iş-aile yaşamı arasında rol çatışması yaşayan kadının iş-aile hayatının uyumlaştırması konusuna yer verilmiş ve buna yönelik çözüm önerileri belirlenmiştir. Böylece kamu sektöründe çalışan kadının çalışma hayatının aile üzerindeki etkilerini belirlemeye yönelik hazırlanmış 33 sorudan oluşan anketin SPSS.17 veri analizi yöntemi ile bulunan sonuçlar tablolar halinde gösterilerek, değerlendirilmiş ve yorumlanmıştır.

\section{A B S T R A C T}

The subject of this study is the impacts of professional life of women working in public sector on their families. First of all, the concept family was defined, its functions were explained and the changing family structure was defined. Factors which affected the family structure change, their results and the changes of the duties of a family were analyzed. Mentioning the changing position of the woman, explaining the history of her entering professional life and her working in public sector, which is the backbone of this study, the problems she faces in professional life and the duties she takes over in family were told about. Besides, harmonization of professional-family life of the woman suffering from role conflict between these two lives was handled and solutions towards this were suggested. In this respect, through the SPSS 17 analysis of the 33 question survey prepared to determine impacts of professional life of women working in public sector, results were given in tables, evaluated and interpreted.

\section{Giriş}

İnsanlar sosyal bir varlık olarak dünyaya gelmiş ve bu pratik, yaşamanın bir ön koşulu olarak süregelmiştir. Sosyal bir varlık olan insan belli bir toplumda, kültürde toplumsallaşma sürecine girmiştir. Bu toplumsallaşma süreci ilk olarak toplumun şekillenmesinde etkili olan toplumun temeli ve çekirdeği olarak nitelendirdiğimiz aile kurumunda başlamıştır. Bu nedenle de güçlü, sağlıklı, bilinçli ve düzenli ailelerin varlığı beraberinde sağlam ve güçlü bir toplumu ortaya çıkaracaktır. Le Play de ailenin önemini, toplumun en

\footnotetext{
* Sorumlu yazar/Corresponding author.

e-posta: adem.palabiyik@hotmail.com
}

küçük birimi olan aile ile organizmanın en küçük birimi olan hücre arasında benzerlik kurarak aile sağlamsa toplum da sağlamdır demektedir. Fizikçi için atom, biyolog için hücre ne ise toplumun doktoru olan sosyolog için de aile aynı anlamdadır diyerek vurgulamıştır (Önel, 2006: 5).

Toplumun en küçük birimi olan aile hakkında bilgi sahibi olmak için toplumun kadınlığına bakmak gerekir, Aslantürk ve Amman'nın (2001) da belirttiği gibi gerçekte bir içtimai zümrenin aile hayatı hakkında esaslı bir fikir sahibi olabilmek için önce zümredeki kadınlığın durumuna göz 
atmak gerekmektedir. Çünkü kadın özellikle Türkiye toplumunda geleneksel dönemden itibaren eril tahakkümün ve cinsiyete dayalı iş bölümünün getirdiği sorumluluk ve görevlerde alanını daraltarak aile içinde var olması gerektiğini belirlemiştir. Uzun yıllar bu alana sıkıştırılmış olan kadın gerek biyolojik olarak üstlendiği roller gerek de toplumun ona yüklediği sorumluluklardan yola çıkarak aile inşası ve gelişmesindeki temel aktör konumunda olmuştur. $\mathrm{Bu}$ nedenle aile kurumunun mimarı olarak nitelendirirsek pek de abartmış sayılmayız. Kadının bu konumu ve aileye katkılarının yanı sıra sanayileşme süreci ile birlikte çeşitli sebeplerden kaynaklı olarak görev ve sorumluluklarına yenileri eklenmiştir. Ev alanı ile sınırlanmıș annelik, karılık ve hane içerisinde ücretsiz işçi olarak çalışan kadın artık hane dışında ücret karşılığı çalışmaya başlamıştır. Kısacası sanayi devrimi ve sonrasında gelişen dünya ekonomisi erkekler kadar olmasa da kadınlar için de istihdam olanağ yaratmıştır. $\mathrm{Bu}$ süreçle hızla gelişmeye başlayan işgücü piyasası kadınların da var olduğu bir alan olmaya başlamıştır. Kapitalist üretim sürecinde kadın, toplumsal üretime katılma imkânı bulmuştur. Ancak kapitalizm, kadını "özel alan" olan evden tam anlamıyla kopartamamış, kadını çift yönlü sömürü ile karşı karşıya bırakmıştır (Güner, 2008: 17). Bu bağlamda modern yapıda toplumsal cinsiyet kavramı içerisinde erkeklere ve kadınlara atfedilen rollerin en önemli etkisi kadın mesleği ve erkek mesleği olarak yapılan ayırımda kendisini gösterdiği söylenebilir. Toplumun cinsiyete bağlı olarak meslek yöneliminin gelişmesi, iş bulma, çalışma hayatında kişisel gelişim, görevde yükselme, olumsuz tutum ve davranışlar, aile ve iş yaşantısının dengesi gibi konularda da kendini göstermektedir.

Kadının emek piyasasında yer alması, aile ve ülke gibi konularda önemli yer tutar. Ancak tam olarak kadınlara yönelik bir çalışma ortamının oluşturulamamış olması, yasal düzenlemelerin eksik kalması ve en önemlisi geleneksel zihinsel kodların bu olguyu tam olarak sindirememiş olmasından kaynaklı olarak birçok sorunu da beraberinde getirmiştir. Bunlardan en önemlileri de işe alınmada cinsiyete dayalı ayrımcılık, aile düzeninde ortaya çıkan sorunlar, ev işlerinden dolayı fiziksel olarak tükenmişlik, çalışma ortamında fiziksel ve zihinsel yorgunluk, stres, gerginlik ve mobbing gibi sorunlar görülmektedir. Bütün bu zorluklara göğüs geren, çalışan kadınlar 1lımlı çalışma koşullarından dolayı kamu alanında kendilerine yer edinmeye çalışmışlardır. Sanayileşmeyle birlikte kadının ücretli çalışması ve savaş dönemlerinde erkeklerin çalışmasına alternatif bir seçenek olarak kamu alanına girmesiyle kendilerine bu sektörde yer almayı başarmışlardır. Kamu sektöründe çalışmak, kadınlar için diğer alanlara göre daha çok tercih edilmiştir. Çünkü kamu sektöründe kadının adresi bellidir, kamu sektörünün, sosyal güvencenin sağlanacağı, çalışma saatlerinin daha belirgin kılınacağı ve ailevi yükümlülüklerini uzlaştırma bakımından da daha hoşgörülü bir alan oluşturacağı kanısındadırlar. Bu nedenle de kamu şemsiyesi altında kendilerine yer edinmiş olsalar da bu şemsiye altında çeşitli hakları yasal olarak elde etmelerine rağmen üstlendiği rollerin yoğunluğundan kaynaklanan çatışmalardan sıyrılmayı becerememişlerdir.

\section{Ailenin Tanımı ve Özellikleri}

Bütün toplumlarda var olan aile kavramı oldukça geniş bir yelpazeye sahiptir. Her toplumun oluşturduğu kültür ve medeniyetler kavrama farklı anlamlar yüklemişlerdir. Bu nedenle de ailenin evrensel bir tanımını yapmak oldukça güçtür. Ancak en klasik tanımıyla toplumun çekirdeğini oluşturan bu birliktelik, toplu halde yaşama kavramını içinde barındığı için, aile kavramı bireylerin hayatlarındaki en önemli unsurlardan biridir. Aile üyelerinin aralarında kan bağı ya da evliliğe dayalı bir ilişki bulunmaktadır ve aileyi oluşturan bireyler birbirlerinin biyolojik, ekonomik, psikolojik, sosyal ve kültürel ihtiyaçlarını karşılamaktadırlar (Doruk, 2008: 34). Aile genel bağlamda "biyolojik ilişkiler sonucu insan neslinin devamını sağlayan; toplumsallaşma sürecinin ilk olarak ortaya çıktı̆̆l; karşılıklı ilişkilerin belirli

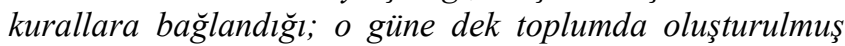
maddi ve manevi zenginlikleri kuşaktan kuşağa aktaran; biyolojik, psikolojik, ekonomik, toplumsal, hukuksal vb. yönleri bulunan toplumsal bir birim olarak nitelendirmektedir" (Adak, 2012: 40). Bunun yanında (Özgüven, 2001) evlilik bağıyla başlayan, akrabalık ve sosyal bağlarla birbirlerine bağlanan, çeşitli rollere sahip, birbirlerini etkileyen, çoğunlukla aynı evde yaşayan fertlerden oluşan, üyelerinin psikolojik, sosyal, kültürel ve ekonomik ihtiyaçlarını karşılayan bir birim olarak da tanımlanmaktadır (Günindi ve Giren, 2011: 351). Aile kavramlarının bu farklı tanımlarına rağmen kavramla ilgili tam anlamıyla tek bir tanımlama yapılması mümkün olmamıştır; ancak hepsinin üzerinde durduğu ortak noktalar mevcuttur. Bu ortak noktaları genel olarak şu şekilde ifade edebiliriz: Toplumun yapisinda ve sosyal sistemin işleyişinde ailenin de bir müessese olarak önemli bir yeri vardır. Bilindiği gibi aile, nüfusu yenileme, milli kültürü taşıma, çocukları sosyalleştirme, ekonomik, psikolojik tatmin fonksiyonlarının yerine getirildiği bir müessesedir. Bu müessese Türk toplumunda da önemli bir yere sahiptir. Ayrıca Anayasanın 41. Maddesine göre, Türk toplumunun temeli ailedir. Aile bir vasıta olduğu için değil, tabi ve gaye olduğu için ferdin mutluluğunun, üzüntülerinin ilk paylaşıldığı birim olduğu için temeldir (Erkal, 2011: 109).

Ailenin bütün toplumlarda ortak bazı özellikleri bulunmaktadır. Aile bağlamında temel özellikler; toplumsal kuralları içermesi ve bunları denetlemesi; duygusal bir temele dayanması; toplumun betimsel bir yansıması olarak kabul edilmesi; çocuğun toplumsallaşması da aile içinde gerçekleştiği için, kişilik gelişmesinde temel bir ortam oluşturması; başka kurumların yerine getirdiği işlevlerde bir kaynaklık etmesi ve meşruiyet sağlaması; örneğin, çocuğun eğitimi, ekonomik etkinlikleri boş zamanı değerlendirmesi bu durumu analiz etmek için önemlidir (Lale, 2004: 11).

\subsection{Ailenin Fonksiyonları ve Yapısı}

Aile, kendi içselleştirdiği kurallar ve bu kurallara uyan üyelerden oluşmaktadır. Bu yapıda bireylerin yerleri ve amaçları belirlidir. Böylece birey, maddi yahut manevi birçok ihtiyacını bu çerçeve içinde giderme şansına sahiptir (Alp, 2007: 29). "Вu nedenle ailenin fonksiyonlart kolaylaştırıcı, arabulucu, uyum sağlayıcı ve birbirlerinden farkll yetenek ve potansiyele sahip üyeler için koruyucu bir sistem olarak oluşturulmalıdır. Sağllklı bir ailenin görevleri; üyelerinin kapasitelerini geliştirmek, çocukların sosyalleşmesini gerçekleştirmek, üyelerin işlevselliklerini sürdürdükleri organizasyonların taleplerini karşılamada yardımcr olmak, ailenin refah için gerekli olan fiziksel ve ruhsal çevreyi oluşturarak üyelerin doyum sağlamasını 
temin etmektir" (Özek, 2011: 70). Ailenin bu yapısalişlevselci özelliği (Koyuncu, 2013: 45-46) sonucunda aile içinde güçlü ilişki biçimleri ortaya çıkar ve sadakat, samimiyet, dürüstlük ve yardımlaşma gibi olgular daha da pekișir. Bu olgulardan herhangi birine uymama yahut sadık kalmama sonucunda ise ailede şiddet, sadakatsizlik yahut ihmal gibi durumlar ortaya çıkar. Böyle durumlarda bireyler boşanmaya kadar sonucu götürebilir. "Çiftlerin, evlilikten zevk almamaya başladığ zaman çözüm olarak görebildiğ $i$ boşanmaya ilişkin olgular çeşitlidir. Sosyo-ekonomik sebepler, duygusal sebepler, cinsel uyum, dinsel olgular, çocuk sahibi olma ya da olmama durumu, boşanma üzerine etkisi olduğu bilinen faktörlerdendir" (Alp, 2007: 30). Böylece aile, bir anlamda işlevsel bir niteliğe de kavuşmuş olur. Yani, ailedeki kurallar ve sevgi ortamı devam ettiği müddetçe, bireyler arasında anomik durumlar, işleyiş açısından sorunlu görünse dahi, bir noktada gidişata uyum sağlamakta ve süreci yeniden rayına oturtmaktadır. Macionis, ailenin bu işlevini ise şu vurgularla izah etmektedir; "Sosyalizasyon ailenin birincil işlevidir. Çünkü ailenin ilk ve en önemli işlevi çocuk yetiştirmektir. İdeal olarak ebeveynler, çocuklarının toplumun diğer üyelerine katılabilmeleri için en iyi şekilde entegre olmasına yardım ederler / Ailenin ikincil önemli işlevi ise, cinsel etkinliğin düzenlenmesidir. Her toplumda mülkiyet haklarının ve akrabalık organizasyonlarının sürdürülmesi amacıyla cinsel etkinlik kurula bağlanmaktadır. Hangi ilişkilerin evlilik dâhilinde olacă̆ da toplumdan topluma değişmektedir / Ailenin en önemli üçüncül işlevi ise, ebeveynlerin doğumla birlikte çocuklarına kendi ırk, etnisite, din ve sosyal sınıf gibi sosyal kimliklerini aktararak toplumsal örgütlenmenin devamına ve korunmasına yardımcr olunmaktır / Ailenin en önemli işlevinden bir diğeri ise maddi ve duygusal güvenlik ve yeterliliği sağlamaktır. Birçok kişi aileyi, fiziksel koruma, duygusal destek ve mali yardım sunan "kalpsiz bir dünyanın cenneti" olarak görmektedir. Bu nedenle de ailesiyle yaşayan insanlar varlıkl ve yalnız yaşayan insanlardan daha sağllklı ve mutlu olduğu söylenmektedir" (Macionis, 2012: 46-48). Aynı katkıyı Parsons da yapmaktadır. İşlevsel bir niteliğe sahip olan aile, Parsons'a göre, çocukların toplumsallaşması ve ailenin üyelerinin ihtiyaçlarının karşılanması ile doğrudan ilgilidir (Barret, 1980).

Değişen toplumsal koşullarla birlikte toplumun en temel birimi olan aile kurumu tanımı, yapısı, türleri ve işlevleri bakımından önemli bir değişim sürecinden geçmektedir. Tarihsel süreç içerisinde aile, özellikle kentleşme ve sanayileşme ile birlikte geleneksel geniş aile yapısından çekirdek aileye dönüşmekte; geleneksel akrabalık bağları zayıflamakta ve ailenin ișlevleri farklılașmaktadır. İşlevlerinin bir kısmını diğer kurumlara aktaran aile yapısı içerisinde boşanma evlilik dışı doğum ve tek ebeveynli aile oranları, yeniden evlenmeler sonucu üvey aile oluşumları, evlenmeksizin birlikte yaşamayı ya da bekâr kalmayı tercih edenlerin sayısı her geçen gün artmaktadır (Adak, 2012: 62). Ailenin yapısının ortaya çıkmasında, şekillenmesinde ve değişiminde rol oynayan önemli etkenler vardır. $\mathrm{Bu}$ etkenlerden en önemlisi aile üyelerinin hâkimiyeti bakımından aile yapısındaki değişmelerdir. Hâkimiyet bakımından aile; önce totem ailesi daha sonra ana ailesi, baba ailesi, pederşahi aile, pederi aile ve modern aile olarak değişim göstermiştir. Ailenin büyüklüğüne göre ise; geleneksel aile (geniş aile) ve çekirdek aile (dar aile) olarak ikiye ayrılmaktadır (Arslantürk ve Amman, 2001: 291).
Kültürden kültüre ve zaman içinde ailede meydana gelen değişiklikler ailenin her dönemde önemini koruduğuna da işaret etmektedir. Ailenin yapısındaki değişimi vurgularken, toplumun yapısının aileyi etkilemesinin yanında, ailenin de toplumu etkilemesini göz ardı etmemek gerekmektedir (Önel, 2006: 9). Endüstrileşme süreci beraberinde sosyokültürel alandaki gelişmeleri de getirmiştir. Bu da geleneksel geniş ailenin değişerek çekirdek aileye dönüşümünü sağlamıștır. Çekirdek aileyse, ailenin fonksiyonlarında da farklılaşmalara sebep olmuştur. Aile içi ilişkiler ve rollerin değişmesi, aile gelirinin kimi durumlarda yetersiz kalış1, çocukların eğitim konuları gibi nedenler ailenin, geleneksel geniş aile özelliği olan üretici yapıdan, tüketici hale gelmesine neden olmuştur. Ailenin tüketici birim haline gelişi ile kadının ev dışındaki islerde çalışmaya başlaması arasında paralellik bulunduğu görülmektedir (Önel, 2006: 12; Can, 2014: 53-54).

\subsection{Aile ve Kadının Çalışma Hayatında Yer Alışı}

Bilindiği gibi kadın, tarihsel süreçte ekonomik işlevsellik başta olmak üzere pek çok pratikte yer almıştır. Lakin sanayi devriminin, çalışan kadın hayatına yaptığı katkı ayrı bir öneme sahiptir. Çünkü sanayi devrimi ile birlikte çalışan kadın, belirli bir ücret karşılığında emeğini satar hale gelmiştir. Bu bağlamda sanayi devrimi, ücretli kadın iş gücü için önemli bir mihenk taşıdır. "Bir başka deyişle XIX. yüzyılda başta İngiltere olmak üzere, birçok Batılı ülkede sanayileşme, dokuma imalatı ile başlarken toplam işgücünün önemli bir bölümünü de kadınlar oluşturmuştur" (Kocacık ve Gökkaya, 2005: 197). Bu nedenle Sanayi Devrimi kadınların işgücüne katılımlarında yaşanan değişimler için bir dönüm noktasıdır (Can, 2013b: 82). Çünkü sanayi devrimi öncesinde kadınlar cinsiyete dayanan iş bölümüne göre: köylerde buğday ve hayvan yetiştirilmesi, yün eğrilmesi ile kasabalarda çamaşırcı, terzi, hizmetçi ya da ebe olarak çalışsa da temelde çocuk doğurmak ve büyütmek, ev işi yapmak gibi geleneksel olan ev kadınlığı rollerinin dışına pek çıkamamışlardır. Fakat sanayi devrimi ile bu durum ücret karşılığı emek piyasasında yer almak olarak şekil değiştirmeye başlamıştır. Bununla beraber, kilit noktası sanayi devrimi olsa da, II. Dünya Savaşı ile kadın işgücüne olan talep artmaya başlamış, günümüzde küreselleşmenin de etkisi ile kadınların emek piyasalarındaki konumları ve sayılarında artış gözlemlenmektedir (İnce, 2010: 59). Türkiye'de ise kadının işgücüne girmesi, diğer batılı ülkelerde yaşanan ekonomik gelişmeler gibi olmamış, bir zorunluluk sonucu oluşmuştur. Çünkü I. Dünya Savası sırasında erkeklerin çoğunun orduya katılması sonucu azalan işgücüne takviye yapmak üzere kadın işgücüne olan talep daha da artmıştır (İnce, 2010: 61). Özer ve Biçerli (2003: 58) ise kadının savaşa giden erkeklerin üretimdeki yerini doldurduğunu ve ev ortamında da erkeğin para kazanma işlevini yüklendiğini belirtmektedir. Böylelikle Avrupa'daki hem cinslerinden bir yüzy1l sonra sanayi üretimine girme nedenleri de farklılaşmaktadır (İnce, 2010: 61).

Cumhuriyetin kurulmasıyla birlikte, ülkemizde birçok alanda köklü değişiklikler yapılmış ve yeni süreçler başlatılmıştır. Bu ilerleme adımları ile birlikte, kadınlar için de önemli yasal düzenlemeler yapılmış ve özellikle ülkemiz için cumhuriyet, sanayi devrimi gibi kadınların çalışma hayatına katılabilmesi adına dönüm noktası haline gelmiştir. Bu kanun, Türkiye'de devletin sosyal politika alanında kadın 
işçileri koruma amaçlı ilk müdahalesidir (İnce, 2010: 62). Lakin özellikle 1950'lerden sonra kadın gerçek anlamda çalışma hayatına katılabilmiştir. Yaşanan göç olayları ve kentleşme, aile ilişkilerini değiştirmiş ve bu değişimler, kadının toplumsal statüsü hakkındaki bazı kalıp yargıların ortadan kalkmasına neden olmuştur. Bu değişimlerle birlikte kadın özellikle eğitim alanında ciddi ilerlemeler sağlamış, hizmet ve diğer sektörlerde tercih hakkına sahip olmuş ve kendini geliştirmeyi becerebilmiştir. Bu pratiklere rağmen geleneksel yapı kadından vazgeçmemiş ve kadının etrafındaki çizgiyi yeniden çizmeye çalışmıştır. İşte bu geleneksel yapı, her ne kadar teorik düzeyde kadınla ilgili önemli gelişmeler yaşansa da, kadının toplum içerisindeki algısının değişmemesine, pratikte ise bu algının devam etmesine neden olmuştur (Atım, 2003).

\section{Kamusal Alan ve Kadın}

Kamu hizmeti Anayasa Mahkemesince, devlet ya da diğer kamu tüzel kişileri tarafından ya da bunların gözetimi altında, genel ve ortak gereksinimlerini karşılamak, kamu yararı ya da çıkarlarını sağlamak için yapılan ve topluma sunulmuş bulunan sürekli düzenli etkinliklerdir (Anayasa Mahkemesinin; 9.2.1994 gün ve E.94/43, K.94/42-2 sayılı kararı: R.G. 24.1.1995-22181 aktaran: Gülakan, 2013: 19). Kamu hizmet türleri; İdari Kamu Hizmetleri, İktisadi Kamu Hizmetleri, Sosyal Kamu Hizmetleri, Bilimsel - Teknik Kültürel Kamu Hizmetleri olarak sınıflandırılmaktadır ve bu hizmetler memur, sözleşmeli personeller, işçiler, geçici personeller tarafından yürütülmektedir (Gülakan, 2013: 1925). Türkiye'de kamu sektörü istihdamı, bakanlıklar, yerel yönetimler, üniversiteler ve KİT'lerdeki memur, sözleşmeli personel, işçi ve mevsimlik işçileri kapsamaktadır. Kamu sektörü hem tarım dışı istihdam edilenler içerisinde hem de ücretlilerin içerisinde çok önemli bir paya sahiptir. Kadınlar için kamu sektöründe çalışma tercih edilen bir durumdur. Kadının, adresi belli, sosyal güvence sağlayan, ailevi yükümlülüklerini uzlaştırma bakımından, gerektiğinde göreli hoşgörü bulabileceği kamu sektörü, en temel istihdam alanıdır. Kadınlar için mesleğin güvenliği büyük önem taşımakta olup kamu sektörüne duyulan güven demek devlete duyulan güven demektir. Kamu kesiminde çalışan kadın sayısı bu faktörlerinde etkisiyle yıllar itibariyle artış göstermiştir (Yumuş, 2009: 14-15).

Kadınların bazı meslek gruplarını daha çok tercih etmesi, ücret ayrımı ya da biyolojik ayrımdan ziyade toplum içinde yaşanan cinsiyet ayrımından ortaya çıkmaktadır (Kahraman, 2014: 84). Bu ise kadınların toplumun yönlendirmesine bağlı olarak iş gruplarını şekillendirdiğini göstermektedir. Günümüzde çalışılan sektörler incelendiği zaman, hizmet sektörü kadınların çalışmayı en çok tercih ettikleri alandır. Çalıştığ 1 sektörde erkeklere kıyasla daha az para kazanan, işbölümü ve yöneticilik pozisyonlarına ulaşmakta ayrımcılık ile karşılaşan taraf yine kadınlardır. Bu açıdan bakıldığında, cinsiyetin meslek sınıflandırmalarında bir araç olarak kullanıldığ̀ görülmektedir (İnce, 2010: 77). "Bu durum kadının genel olarak çalışma yaşamında özellikle de savaş zamanlarında "yedek işgücü" olarak kullanıldı̆̆ını doğrulamaktadır. Dünyanın pek çok ülkesinde olduğu gibi ülkemizde de bunalım ile savaş dönemlerinde kadınlar gerektiği zaman işgücü boşluğunu doldurmak üzere bekleyen bir kitle olarak görülmektedirler. Tam anlamıyla Türkiye'de kadinlar 3 Mart 1924 tarihinde Tevhidi Tedrisat
Kanunu'nun kabul edilmesinden itibaren yasalarla kamu yönetiminde görev alma hakkını elde etmişlerdir" (Yumuş, 2009: 14). Türkiye'de çalışan kadınlar göz önünde bulundurulduğunda, hem tarım dışı istihdam edilenler içerisinde hem de ücretlilerin içerisinde kamu sektörü çok önemli bir paya sahiptir. Kadınlar için kamu sektöründe çalışma tercih edilen bir durumdur. Bu tercihte devlete duyulan güven, düzenli çalışma şartları sağlaması gibi faktörler etkili olmaktadır (Yumuş, 2009: 2). Tarımdan sonra kadınların en fazla iş olanağı bulduğu sektör, hizmet sektörüdür. Kadınların kendilerini daha iyi ifade etmelerine şans vermesi ve işlerin kadınlara hitap etmesi, hizmet sektörünün seçilmesindeki başat nedenlerdir. Sanayi sektöründeki azlığın temel sebebi ise ucuz emek ve işlerin yoğunluğundan dolayı yüksek fiziki güçtür (Atım, 2013: 89). Bu sebeplerden dolayı kadın, ev ile iş arasında kalmakta ve kadına ev ile alakalı olan misyonlar yüklenmektedir (Yılmaz vd., 2008: 96). Bu yüklemeler ise kadını başka alanlara çekmiş ve kadın, "ev”e uygun olan meslekler perspektifinde tercihlerini geliştirmişlerdir. Öğretmenlik, hemşirelik ve sekreterlik gibi annelik ve eş olmanın uzantısı olan meslekler, bunların bazıları olmuştur. Bunlarla birlikte, çalışma saatlerinin belli olması ve iş güvencesi de yine kadınların yukarıda ifade ettiğimiz meslek türlerine yönelmelerine sebep olmuştur (Kocacık ve Gökkaya, 2005: 207).

Kadınların mücadele süreçlerini bazı sembolik durumlarla analiz etmeye çalışan modern toplumda, farklı uygulamalardan dolayı kadınların bir takım sorunlar yaşamaya devam ettiği görülmektedir. Sanki bir destekmiş gibi sunulan bazı günler, aslında kadınları daha fazla etki altına alan bir sürece itmiştir. Bunun en çok bilinen örneği ise uluslararası kadın mücadele gününe dönüştürülen 8 Mart Dünya Kadınlar Günü'dür (Bilgin, 2012: 311). Türkiye'de ise durum dünya genelinden biraz daha ağır ve farklıdır. Batı karşısında ülkemizdeki kadınları hakları göreli olarak iyileştirilse de, geleneksel kodlar kadına muhakkak çifte yükümlülük getirmektedir. Çalışma yaşamıyla beraber yükü daha çok artan kadınlar olumsuz iş koşulları ve toplumsal baskılarla da başa çıkmak durumunda kalmaktadır (Güner, 2008: 11). Terri Apter'e göre kadınlar iki zıt ama önemli olguyu aynı zanda istemektedirler, bunlar iş hayatı ve anneliktir. İki olgu da akla uygundur lakin ev işlerindeki sorumluluk erkekler tarafından kadınlara yüklendiği için iş yaşamının esnekliği kadınlara kolaylık sağlamalıdır, çünkü erkeklerin tutumunun değişmesi daha zordur (Giddens, 2008: 258). Çalışan kadının bu bağlamda temel problemi annelik ve ev olmuştur. Çünkü ev işleri ve çocuk bakımı gibi konular kadına atfedilenler arasındadır (Hıdıroğlu, 2006: 13). Taraflı perspektiften bakıldığında kadının çalışma hayatına girememe nedenleri arasında uygun iş güçlüğü, çalışma şartları, eğitim, meslek, çocuk bakımı gibi konular gelmektedir. Kadının çalışma nedenlerinin başında ise özellikle ekonomik süreç gelmektedir. Tek maaş ile geçinememe pratiği, kadının çalışma hayatına girmesi açısından önemlidir. (Aksoy ve Şahin, 2005: 284). Bunların yanında, çalışan kadınlar için çocuk bakımına dâhil olan kreş sorunu da başat problemler arasındadır. Kadının, erkek emeğine karşı bir tercih olarak sunulması ve ucuz iş gücüymüş gibi algılanması da ayrı bir problemdir. Belki de en önemli ve ahlaki bir problem ise taciz meselesidir. Taciz sorunu hemen her kadının yaşadığı problemlerin başında gelmektedir. Sırf kadın olmaktan dolayı yaşanılan bu 
problem, günümüz çalışan kadınları arasında kabul edilen başat sorun olarak karşımıza çıkmaktadır (Yılmaz vd., 2008: 93). Bu sorumluluklara bakıldığı takdirde, çalışan kadınların eşlerinin, aile içi işlevsellik sürecinde eşine destek olması, ev ișleri yahut çocuk bakımının paylaşılması gibi müşterek hususlarda yardımcı olması hayatın doğal bir getirisi olmakla birlikte hayatı daha da kolaylaştıracaktır (Önel, 2006: 50). Böylece aile içi gerginlikler yahut olası çatışmalardan da uzak kalınacak ve aile huzuru korunmuş olacaktır. Erkeklerin kadınlara oranla daha fazla çatışma ortamı içinde olduğunu (Çakırbenk, 2011: 174) varsayarsak, iş ve aile arasındaki hayat uyumunu yakalayabilmek için, huzurun mimarı olmak ve rol çatışmasını sona erdirmek başlıca tercihler arasında yer almalıdır. Ailedeki sorumluluk paylaşımı aile üyelerinin (ebeveynlerin) üzerine düşen sorumlulukları yerine getirerek iş ve aile hayatlarının uyum içerinde geçmesini sağlamalıdırlar. Ancak bu geleneksel yapının belirlediği şekilde değil de içinde yaşadığımız çağın gereklerine ve getireceği sorunlara göğüs gerecek şekilde yapılması gerekmektedir. Yani nasıl ki çalışan kadın erkeğe atfedilen geçim sorununu yükleniyorsa aynı şekilde erkek de cinsiyetçi yapının kadına atfettiği rolleri arasında kendine pay edinmelidir. Ailenin en önemli işlevlerinden biri çocuğun eğitimi ve sosyalleşmesidir. Büyüme evresinde olan çocuk özellikle iki yaşına kadar anne sevgisi ve ilgisine ihtiyaç duymaktadır. Bu kritik evrede bu ilgiden yoksun büyüyen çocuklar güvensiz, azami anne sevgisinden mahrum ve kendini gerçekleştiremeyen çocukların gelişimini beraberinde getirir (Can, 2013a: 235). Bu nedenle çocuğun eğitimi ve sosyalleşmesinde aile kurumunun önemi büyüktür. Özellikle küçük yaştaki çocuklar anne sevgisi ve şefkatine ihtiyaç duyarlar. Erkal, "Şu halde, ilk eğitim ana kucağındaki ve daha sonra aile ocağındaki eğitimdir" diyerek ailenin ve özellikle annenin çocuk için önemini vurgulamaktadır. "Iyi yetişmiş ve eğitilmiş kadın hem toplum hayatında daha tesirli olabildiği gibi, aynı zamanda ĕgitimci rolü oynar" (Kayadibi, 2003: 20). Anne çocukla bu süreci yaşarken üstlendiği diğer rolleri de beraberinde yürütebilmesi için aile bireyleri arasında görev ve sorumluluklar paylaşılarak yerine getirilmelidir.

İş yaşamı ve çocuk bakımı arasında gerilim Türkiye'de çalışan kadınları zor durumda bırakmaktadır. Bu gerginliği çözmek üzere Avrupa ülkeleri bazı politikalar geliştirmişlerdir. Türkiye'de ise devletin çocuk bakımı ile ilgili olarak herhangi bir sübvansiyon uygulaması söz konusu değildir. Kadınların çalışma yaşamı doğumla birlikte kesintiye uğrayabilmektedir. $\mathrm{Bu}$ kesintiyi göze almak istemeyen kadınlar sosyal yaşamlarında bir ikilem yaşamakta çocuğuna bakmak ve çalışmak arasında bir tercih yapmak zorunda kalmaktadırlar. Birçok kadın çocuk bakım maliyetleri dolayısıyla, çocuğuna ücretli bakım sağlayıp ek bir harcama yapmak yerine, doğumla birlikte çalışmayı bırakıp çocuğuna kendisi bakmayı tercih etmektedir. Türkiye'de devletin çocuk bakım maliyetlerine ilişkin yapacağı desteğin çalışan kadın oranının artmasında önemli bir etkisi olacağı açıktır (Yıldırım ve Canatan, 2011: 23). Yani çalışan kadının en önemli sorunu olan çocuk bakımına üretilecek olan çözüm bir nebze de olsa içini rahatlatacak ve daha verimli olmasını sağlayacaktır. Böylece çalışan kadın için en önemli vaka olan çocuk bakımı işveren tarafından önemsenecek ve işyerlerinde kreş ve çocuk bakım merkezleri gibi türevler açılacaktır (Önel, 2006: 54).

\section{Yöntem}

\subsection{Araștırmanın Kapsamı ve Yöntemi}

Bu araştırma, 2017-2018 yılında Muş il merkezinde kamu sektöründe çalışan evli kadınları kapsamaktadır. Bu bağlamda, örnekleme yöntemi ile seçilen 84 kamuda çalışan evli kadın üzerinde gerçekleştirilmiştir. Araştırmanın amacı, kamu sektöründe çalışan evli kadınların çalışmasının aile üzerindeki etkilerini ortaya koymak için gerçekleştirilmiştir. Araştırma için Kasım-Aralık 2017 ve Ocak 2018'de çalışmalara başlanmıştır. Bu çerçeve de konu ile ilgili çeşitli bilimsel araştırmalara ve kavramsal çerçeveyi oturtacak kitap ve yazılara ulaşılmıştır. Daha sonra soruların hazırlanması için çalışmalara başlanmıştır. Soruların hazırlanmasında, anket uygulamadaki zorluklar dikkate alınarak, sade, anlaşılır bir dil tercih edilmiş ve soru sayısı 33 ile sınırlandırılmıştır. Hazırlanan sorular ön bir uygulamaya sokulmuş ve pilot olarak seçilen kamu kesiminde 30 çalışan kadın üzerinde uygulanmıştır. Alınan sonuçlar değerlendirilerek sorular yeniden gözden geçirilmiş ve bazı düzeltmeler yapılarak basımı sağlanmıştır. Araştırmanın evreni olarak Muş ilinin kamu sektörü içerisinde, muş devlet hastanesi, toplum sağlık merkezi çeşitli okullar ve diğer kamu kurumlarında çalışan kadınlar seçilmiştir. Örneklem seçiminde evren sayısı belirli olduğu için $\alpha$ : 0.05 için 1.96 değeri seçilmiş, ayrıca p: 0.5 ve q: 0.5 değerleri alınmıştır (Yazıcıoğlu ve Erdoğan, 2004: 50). Çalışmanın hata payı olarak 0.05 örneklem hatası kabul edilmiş ve toplamda 84 çalışan bayana ulaşılmıştır. Örneklem hesaplanması için Özdamar'ın, varyansa bağlamlı örneklem hesaplama formülü kullanılmıştır (Özdamar, 2003: 116-118). Çünkü örneklemin güvenirliliği parametreye yakınlığı arttıkça artmaktadır (Kaptan, 1981: 136). Örneklem, belli kurallara göre, belli bir evrenden seçilmiş ve seçildiği evreni temsil yeterliliği kabul edilen küçük kümedir (Karasar, 2005: 110-111). Örneklem sayısı ise bu alanlarda çalışan 28 hemşire 28 öğretmen 3 doktor ve 25 mühendis, sekreter, veteriner hekim vb. alandan seçilmiş toplam 84 çalışan kadındır. Sosyo-ekonomik açıdan kategorik dağlım bazı mesleklerde fazla olmasının sebebi ise, Muş ilinde evli ve bayan olarak tercih edilen sayının, kurumları içindeki azlığa ve iletişim kurmanın zorunluluğuna dayanmaşıdır. $\mathrm{Bu}$ bağlamda bazı meslek sayıları fazla olsa da her mesleğin dâhil olması sağlanmaya çalışılmıştır. Bu çalışmada ise iki tür örneklem çeşidi kullanılmıştır. İlk amaçlı örneklemdir ki, bu örneklem evrenin genelini temsil edecek bir örneklem seçme amacı taşımaktadır (Özen ve Gül, 2007: 414). Çünkü örneklemden elde edilen sonuçlar evrenle genellenir (Karasar, 2005: 110-111). Bu anlamda olgu ve olayların keşfedilmesinde ve açıklanmasında (Başaran, 2017: 490; Tarhan, 2015) yolumuzu görmemizi sağlar. Kota örnekleme tekniği, araştırmaya dâhil edilecek kişilerin kotalara göre saptanmasına dayanır. Belli özelliklere (yaş, cinsiyet, eğitim vb.) ayrılan kotalara kaç birey ya da birimin yerleştirileceğine önceden karar verilir. Tespit edilen her kota için aynı sayıya dikkat etmek gerekir (Kümbetoğlu, 2008: 100; Şenol, 2012). Amaçlı örneklemde ise araştırmanın amacına dayanan ve belirli bir kriter ve ya özelliğe bağlı olarak seçilen birey ve ya gruplardan oluşan bir yapıyı temsil eder (Kümbetoğlu, 2008: 99). 


\subsection{Araştırmanın Varsayımları ve Öngörüleri}

(i) Kadının eğitim durumunun yükselmesi ve çalışma hayatına girmesi çekirdek aile yapısını yaygınlaştırmışıır;

(ii) Kamu da kadıların toplumun onlara yüklediği sorumluluklara göre istihdam etmekte olduklarını ve bu yönelimde de bir kabullenmişlik söz konusu olduğunu söyleyebiliriz;

(iii) Birçok rolü üstlenip girdiği rol çatışmasına rağmen kadının iş hayatında var olması gerektiği görüşü savunulmuştur;

(iv) Toplumda kadının çalışmasının tam olarak sindirilmemiş olsa bile bu yönelimde çok yol kat edildiğini söyleyebiliriz;

(v) Kadınlar ekonomik özgürlügünü elde etmek için çalışmaktadırlar;

(vi) Kadının ideal yaşam biçimi ev kadınlığı ile iş kadınlığı rollerinin birleştirerek yürütmektir;

(vii) Kadının çalışması aileye ekonomik destek ve sosyal güvence sağlaması nedeniyle olumlu etkilemektedir;

(viii) Kadının çalışması aileye yeteri kadar zaman ayıramamasına neden olmaktadır;

(ix) Çalışan kadınlar aile içerisinde karar almada söz sahibiler;

(x) Kadının çalışması iyi bir anne ve eş olmasını engellemez ikisi arasındaki ciddi bir uyumsuzluk durumunda ailesini seçer;

(xi) Kadınların çalışmalarına yönelik yasal düzenlemeler yetersizdir;

(xii) Çalışan kadınların sorunları ancak yasaların yeniden düzenlenmesi ve toplumda ki zihinsel kodların bu yönelimde değiştirilmesi ile sağlanabilir;

(xiii) Araştırmanın örneklemini oluşturan 84 katılımıının kendilerinden istenilen bilgileri içtenlikle ve doğru olarak cevapladıkları öngörülmektedir;

(xiv) Örneklemin evreni temsil ettiği öngörülmektedir;

(xv) Araştırmada kullanılan ölçme araçlarının ölçtükleri özellikler bakımından güvenilir ve geçerli olduğu öngörülmektedir.

4.3. Veri Toplama ve Kullanılan İstatistiksel Teknikler

Araştırma verilerinin toplanması sürecinde öncelikle gerekli izinler alınmış ve belirlenen kurumlarda uygulama yapılmıştır. Varsayımlarımızda var olduğunu iddia ettiğimiz varsayımlarımıza ilişkin yahut etkinin olup olmadığına dair veya verilerin toplanacağı (Arık, 1992) kaynaklara bakmak gerekir. $\mathrm{Bu}$ bağlamda uygulamada hata yapmamak için gerekli hassasiyet gösterilmiştir. Sorular hazırlanırken, araştırmanın geçerliliği ve güvenirliliğini sağlamak amacıyla, ölçme aracına uygun ve ölçülmek istenen alanı temsil etmesi amaçlanan verilerin içeriklerine uygun olarak, olgusal, kapalı uçlu ve açık uçlu, seçmeli ve çok seçenekli soru tiplerinden oluşmuştur. Uygulama sonucu alınan veriler daha önceden altyapısı hazırlanan SPSS programına ham bilgi olarak aktarılmış ve bu program yoluyla frekans dağılım ve çapraz tabloları çıkarılmıştır. Kay-Kare testi, verilerin analizlerde uygun görülmemiştir, çünkü bu pratik daha çok kesin olasılık dağılımlarını oluşturmak amacıyla kullanılabilir (Agresti, 2002). Daha doğrusu bu testin kullanılabilmesi için beklenen değerin beşten küçük olan kategorik sayının, toplam kategori sayısının \% 20'sini aşmaması ve tüm kategorilerde bu değerin birden büyük olması gerekir (Büyüköztürk, 2014: 142). Bu analizde yapılan Kay-Kare testinde gözenek sayısı, toplam gözenek sayısının \% 20'sini aştı̆g 1 için anlamlılık testine ilişkin sonuçların yorumlanması doğru değildir. İkinci bir sebep ise değisskenlerin kategorik olamamasından dolayı anlamlı bir farklılık gösterip göstermediğini test etmek mümkün olmamıştır. Eğer bir ilişki ortaya konulmak istenseydi (Bakan ve Büyükbeşe, 2004; Bircan vd., 2003: 73), bütün analizlerde Ki-Kare testi uygulanabilirdi. Çapraz tablo, araştırmaya katılan denek ya da katılımcıların, iki ya da daha çok sınıflamalı değişkene göre frekans ve yüzde dağılımını verir. Gözenekler için yüzde değeri incelenerek değişkenler arasında ilişki olup olmadığı konusunda bir fikir edinilebilir. Böylece çapraz tablo, bize en az iki değişkene göre oluşan gözeneklerin satır kenar toplamı, sütun kenar toplamı ve genel toplam üzerinden yüzde değerlerini aynı tabloda görmemizi ve değerlendirmemizi sağlar. Ayrıca ek olarak, herhangi bir konuyla ilgili olarak sınıflamaya ya da sınırlama ölçeğinde belirlenen görüşlerin, sınıflamalı bir değişkene göre oluşan alt gruplar bakımından genel olarak inceleme olanağı sağlar (Büyüköztürk, 2014: 27).

\section{Bulgular}

Burada araştırmanın doğrultusunda toplanan verilerden elde edilen bulgulara yer verilmektedir.

\subsection{Demografik Bulgular}

Demografik bulgular bölümünde, ankete katılan çalışan kadınların yaş, doğum yeri, evlilik, gelir ve eğitim düzeyleri, çalışma yılı gibi verilere yer verilmiştir. Burada temel amaç, ankete katılan çalışan kadınların genel durumunu ortaya çıkarmaktır.

Tablo 1. Basit Frekans Yaş Tablosu

\begin{tabular}{ccc}
\hline Yaş & Yüzde & Kişi Sayıs1 \\
\hline 21-25 Aras1 & 15,5 & 13 \\
26-30 Aras1 & 34,5 & 29 \\
31-35 Aras1 & 38,5 & 32 \\
36 ve Üzeri & 11,9 & 10 \\
Toplam & 100 & 84 \\
\hline
\end{tabular}

Tablo 1'de yaş oranına baktığımız zaman en yüksek oranı 31-35 yaş aralığını \%38.5 ile oluşturduğunu görüyoruz. Bunu takiben 26-30 yaş aralığ \%34.5 ile, 21-25 yaş aralı̆g 1 $\% 15.5$ ve son olarak da 36 ve üzerindeki yaş aralığı da \%11.9 oranını oluşturmaktadır. Bu sonuca bakıldığı takdirde, örneklemin orta yaş düzeyinde yoğunlaştı̆̆ını görebiliriz.

Tablo 2. Yaş ve Çocuğunuz Var Mı Sorularına İlişkin Çapraz Tablosu

\begin{tabular}{|c|c|c|c|}
\hline \multirow{2}{*}{ Yaş } & \multicolumn{2}{|c|}{ Çocuğunuz Var Mı? } & \multirow{2}{*}{ Toplam } \\
\hline & Evet & Hayır & \\
\hline \multirow{2}{*}{$21-25$} & 3 & 10 & 13 \\
\hline & $3,6 \%$ & $11,9 \%$ & $15,5 \%$ \\
\hline \multirow{2}{*}{$26-30$} & 21 & 8 & 29 \\
\hline & $25,0 \%$ & $9,5 \%$ & $34,5 \%$ \\
\hline \multirow{2}{*}{$31-35$} & 26 & 6 & 32 \\
\hline & $31,0 \%$ & $7,1 \%$ & $38,1 \%$ \\
\hline \multirow{2}{*}{36 ve üzeri } & 8 & 2 & 10 \\
\hline & $9,5 \%$ & $2,4 \%$ & $11,9 \%$ \\
\hline \multirow{2}{*}{ Toplam } & 58 & 26 & 84 \\
\hline & $69,0 \%$ & $31,0 \%$ & $100,0 \%$ \\
\hline
\end{tabular}


Tablo 2 incelendiğinde yaşa bağlı olarak çocuğun var olmasına baktığımızda, araştırmaya katılanların 58 bayan (\%69,0 ile) çocuk sahibi olduğunu ve bunların 26's1 (\%31,0 ile) 31-35 yaş arasında olduklarını ve bunu takip eden en yüksek diğer sayının ise 21 bayan ile $(\% 25,0)$ ile 26- 30 yaş aralığını kapsadığını görmekteyiz. Hayır diyen bayan sayısı ise \%31 ile 26 sayısında kalmıştır. Evlenmeyen bayanların ise en fazla 21-25 yaş aralığında yoğunlaştığı yine tablodan anlaşılabilir. $\mathrm{Bu}$ durumun temel sebepleri arasında genç yaştaki bireylerin, daha çok duygusal olmaları yahut duygusal bağlamda alınan kararların evlilik ile ilişkilendirildiği takdirde pek fazla olumlu sonuç vermemesi olarak yorumlanabilir (Süzer ve Y1ldız, 2005; Stahmann, 2000). Doğum yerlerinin bölgesel dağılımına bakıldığında ise örneklemimiz itibarıyla Muş ilinde kamuda çalışan 35 bayanın \%41,7 ile doğu Anadolu bölgesinde yaşadığını ve onu takip eden bölgenin ise 11 bayan ve \%13,1 oranı ile İç Anadolu bölgesi olduğunu görmekteyiz. Aynı zamanda Ege bölgesi ile Akdeniz bölgesinin de \%11,9 (10 bayan) ile Muş ilinde hizmet vermekte olduklarını görüyoruz. Bölge bazlı evlilik dağılım oranlarına bakıldığ zaman ise en fazla evli olan bayanın yine Doğu Anadolu illerinde doğmuş olan bayanların (35 bayan ile \%41,7) olduğunu görebiliyoruz. Evlilik sayısının Doğu bölgelerinde daha yüksek çıkmasını sebebini ise erken yaşta yapılan evlilik algısı ve geleneği ile ilişkili olduğu ifade edilebilir (Orçan ve Kar, 2008: 98-99). Çalışmamıza katılan bayanların eğitim düzeylerini analiz ettiğimiz takdirde, en yüksek oranın 55 bayan $(\% 64,1)$ ile lisans mezuniyetinde olduğunu görebiliriz. Ön lisans mezunu 12 bayan ile $\% 14,5$; master mezunu 10 bayan ile $\% 12$ ve lise mezunu 7 bayan ile \%8,4 olarak karşımıza çıkmıştır. Diğer bil ilginç analiz ise yine en fazla evlilik olan bayan sayısının lisans mezunlarında 52 bayan ile \%61,9 olduğunu görebiliyoruz. Evlilik olgusunun demografik verilerle ilişkisini yukarıda ifade ettiğimiz sebeplerle analiz edebiliriz, kısacası bu olgu özellikle doğum yerine bölgesel gelenek ile oldukça yakından ilgilidir. İncelediğimiz diğer bir analiz olan aylık gelir durumunun en yüksek olduğu oran 39 bayan $(\% 47,0)$ ile 2 bin TL olup bu sayının 29'nu $(\% 34,9)$ lisans mezunları oluşturmaktadır. Bunu takip eden diğer oranlar 3 bin TL ile 35 bayan (\%42,2); 4 bin TL ile 5 bayan $(\% 6) ; 5$ bin ve 6 bin TL ile 2 'şer bayan $(\% 4,8)$ siralanabilir. Gelir dağılımın meslek ile ilişkisine bakıldığı takdirde ise en yüksek oranın 39 bayan ile $(\% 47,0) 2$ bin TL olduğu ve bunun 20 kişisini $(\% 24,1)$ öğretmenlerin oluşturduğunu görmekteyiz. Bunu takip eden diğer yüksek oran ise 35 bayan ile $(\% 42,2) 3$ bin TL olup bunların 23 kişinin $(\% 27,7)$ hemşirelerden oluştuğunu görebilmekteyiz.

\subsection{Sosyo-Kültürel ve Sosyo-Ekonomik Bulgular}

Sosyo-kültürel bulgular kısmında. Özellikle çalışan ve örneklemimizde olan bayanların, varsayımlar üzerinden belirttiğimiz değerlendirmeleri analiz etmeye çalışacağız. Bu bağlamda ilk analizimiz eğitim düzeyinin yükselmesi ile aile türleri arasındaki ilişki olacaktır.

Tablo 3'e bakıldığı takdirde, Eğitim durumu ile Aile yapısının türleri görülmektedir. Tabloda dikkat çeken husus, eğitim oranlarının artması ile çekirdek aile sayısında meydana gelen artış olacaktır. Anketimize katılan çalışan bayanların 7'i $((\% 8,3)$ lise mezunu olduğunu ifade etmiş, bu cevaplardan 5'i $(\% 6)$ çekirdek aile cevabını vermiştir. Yine 12 önlisans mezunu çalışan bayanın $(\% 13,4)$ hepsi, evlilik türü olarak çekirdek aile cevabını vermiștir. Lisans mezunu 54 bayandan $(\% 64,3)$ 48'i $(\% 57,1)$ çekirdek aile cevabını vermişken; 11 master mezunu bayanın $(\% 13,1)$ hepsi yine çekirdek aile cevabını vermiştir. Çekirdek aile, eğitim düzeyi arttıkça sürekli hale gelmektedir. Bunun temel sebepleri arasında ekonomik ve çocuklarla daha fazla ilgilenme vardır (Eyce, 2000: 231). Özellikle aile içi fertlere sağlanan hizmetteki artık, çekirdek aile de daha fazla görülmekte ve ailenin fonksiyonu, diş dünyaya karşı bir sosyalleşme işlevine dönüşmektedir. $\mathrm{Bu}$ durumlar, çekirdek ailelerin artmasına ve sürdürülebilir hale gelmesine sebep olmaktadır. Yine meslek ile aile yapısı analizine baktığımızda ise en fazla çekirdek ailenin öğretmen (26 kiși ile \%31) ve hemşire (26 kişi ile \%31) meslek türlerinde olduğunu görebilmekteyiz. Yine bu durumun temel sebebinin eğitim ile birlikte, mesleğin nitelikleri perspektifinde yer değiştirme de olduğu ileri sürülebilir.

Tablo 3. Eğitim Durumu ve Aile Yapısı Çapraz Tablosu

\begin{tabular}{ccccc}
\hline \multirow{2}{*}{ Eğitim durumu } & \multicolumn{4}{c}{ Hangi Aile Yapısına Sahipsiniz } \\
& $\begin{array}{c}\text { Çekirdek } \\
\text { Aile }\end{array}$ & Geniş Aile & $\begin{array}{c}\text { Parçalanm } \\
\text { 1ş Aile }\end{array}$ & Toplam \\
\hline Lise Mezunu & 5 & 2 & 0 & 7 \\
Ön Lisans & $6,0 \%$ & $2,4 \%$ &, $0 \%$ & $8,3 \%$ \\
Mezunu & 12 & 0 & 0 & 12 \\
& $14,3 \%$ &, $0 \%$ &, $0 \%$ & $14,3 \%$ \\
Lisans Mezunu & 48 & 5 & 1 & 54 \\
& $57,1 \%$ & $6,0 \%$ & $1,2 \%$ & $64,3 \%$ \\
Yüksek Lisans & 11 & 0 & 0 & 11 \\
& $13.1 \%$ &, $0 \%$ &, $0 \%$ & $13.1 \%$ \\
Toplam & 76 & 7 & 1 & 84 \\
& $90,5 \%$ & $8,3 \%$ & $1,2 \%$ & $100,0 \%$ \\
\hline
\end{tabular}

Toplum tarafindan kadın yüklenen sorumluluklar sadece evlilik ile sınırlı değildir. Bu husus meslek ile de yakından ilgilidir. Seçilen mesleklerin toplum tarafindan dayatılması yahut bir tercih olarak sunulması, meslek tercihlerinde de etkili olmaktadır. Meslek tercihi ile meslek ayrımı üzerine yaptığımız analizde, kadınların meslek seçerken çok fazla ayrım yapmadıklarını ve bir ön kabulle geldiklerini görebilmekteyiz. Örneğin, toplamda 84 kamu da çalışan kadından 29'u $(\% 34,5)$ hemşire, 28' i $(33,3)$ öğretmen, 24 'ü $(\% 28,6)$ diğer (veteriner hekimlik sekreterlik mühendislik, memur) ve 3 'ü $(\% 3,6)$ de doktorluk mesleğini yapmaktadır. Bunlara yönettiğimiz meslek seçimi yaparken kadın mesleği erkek mesleği ayırımı yaptınız mı sorusuna 54 kişi $(\% 64,3)$ hayır cevabını verirken 21 kişi de $(\% 25,0)$ kısmen, 9 kişi $(\% 10,7)$ evet cevabını vermektedir. Bu verilerden de hareketle kadınların toplumun onlara yüklediği sorumluluklara göre istihdam ettiğini ve bu yönelimde bir kabullenmişlik söz konusu olduğunu görüyoruz. Yine araştırmaya katılanların çalışma nedenlerinin nereli olduklarına göre dağılımına baktığımız zaman çalışma nedeni olarak en yüksek oranın \%41,7 (35 kişi) ile ekonomik özgürlük olmuştur. $\mathrm{Bu}$ oranın \%16,7' si (14 kişi) Doğu Anadolu bölgesinde iken diğer en yüksek oran \%7,1 ile Ege bölgesinden oluşmaktadır. Bunu takiben diğer çalışma nedeni olarak \%19,0 ile gelecek güvencesi, \%15,5 ile kariyer meslek edinme, \%10,7 ekonomik zorunluluk ve \%9,5 'i de işten elde edilen mutluluktan dolayı çalıştıklarını belirtmişlerdir. $\mathrm{Bu}$ verilerden hareketle geleneksel kadın 
kalıplarının yıkılması ve kadının kendi özgürlüğünü sağlamaya yönelik çalıştığını ve bu durumun doğu Anadolu bölgesinde yoğunluk gösterdiğini söyleyebiliriz. Toplumsal cinsiyet söyleminin, yukarıda ifade edilenler (meslek tercihi, doğum yeri, vs.) bağlamında oldukça etkili olduğu da söylenebilir (Gündüz vd., 2015: 23). Çalışma ve maddi durum ilişkisi üzerine yaptığımız analizde ise çalışan kadınların maddi durumunun yeteri kadar iyi olması durumunda yine çalışır mıydınız sorusuna 47 kişi $(\% 56,0)$ evet, 25 kişi $(\% 25,0)$ hayır ve 16 kişi $(\% 19,0)$ kararsızım cevabını vermiştir. Kadınların büyük bir oranı 47 kişi $(\% 56,0)$ maddi durumunun yeteri kadar iyi olması durumunda yine çalışacağını söylemektedir ve bu oranın mesleğe göre dağılımında (\%21,4 ile) 18'ini öğretmenler, (\%15,5 ile) 13'ünü hemşireler (\%16,7 ile) 14'ünü diğer ve $(\% 2,4$ ile) 2'sini de doktorlar oluşturmaktadır. Maddi durumunun yetere kadar iyi olması durumunda çalışmayacağını belirtenlerin oranı ise 21 kişi ile $\% 25,0$ olup bu oranın büyük kısmını 12 kişi, \%14,3 ile hemşireler oluşturmaktadır. Burada yoğun çalışma koşularına bağlı olarak hemşirelerin çalışma heveslerinin kalmadığını söyleyebiliriz. Bu sonuçlara bakıldığında meslek seçimi ile iş tatmini arasında ciddi bir ilişki biçimini olduğu gözlenebilir. Çünkü mesleklerin yüksek iş tatmini ve düşük iş tatminine göre ayrıştı ğ bilinmekte ve tercihlerin buna göre yapıldığı düşünülmektedir (Gökdeniz ve Merdan, 2016: 112).

Çalışan kadınların çevrelerinden aldıkları tepkilerin de, çalışma hayatı üzerinde önemli etkileri mevcuttur. Kadının toplum tarafından belirlenmiş cinsiyet rollerine göre hareket etmemesi bir bağlamda öngörülerin de belirlenmesine sebep olmuştur. Bu pratiğin kaynağı ise toplumsalın ön gördüğü genelliklerin erkeği baskın tutmak suretiyle kabullenilmesinde yatmaktadır (Bingöl, 2014: 109). Yaptığımız araştırmada da bu bağlamda yüzde yüz istenilen sonuç çıkmamıştır. Kadınların çoğu (59 bayan \%70,2 ile) çevreden aldığı tepkilerin olumlu olduğunu ifade etmiş olsa dahi, geriye kalan 25 bayan $(\% 29,8)$ ile "evet" cevabını verememiştir. Evet, cevabını verenleri yarısı kadar bir sayı hala çevrenin memnuniyetsizliğine işaret etmiştir. Bölgesel dağılım açısından ise şaşırtıcı bir biçimde olumlu tepkiler aldıklarını ifade eden kadınların \%27, 4 ile en yüksek oranın doğu Anadolu bölgesinde olduğunu görüyoruz ve burada ülkemizde kapalı toplum olarak nitelenen doğu toplumunun kadının çalışmasına yönelik olumlu bir tutum sergilediğini söyleyebiliriz. Eğitim ve kadın yaşam biçimi ilişkisine bakıldığında ise çalışan kadınların büyük bir kısmına (52 kadın ile \%61,0) göre kadının ideal yaşam biçimi ev kadınlığı ve iş kadınlığı rollerini birleştirerek yürütülmesidir. Eğitim durumuna göre baktığımızda ise bu oranın (37 kadın ile \%44,0) yoğunluğunu lisans mezunları oluşturmaktadır. Çalışan kadınların bir kısmı da (19 kadın ile \%22,6) geleneksellikten kopamamış olup kadının ideal yaşam biçimi olarak iyi bir anne ve ev kadını olması görüşünü savunmuşlardır. Bunu eğitim durumuna göre değerlendirdiğimizde ise en yüksek oranı 11 kadın ile $(\% 13,1)$ yine lisans mezunları oluşturmaktadır.
Tablo 4. Meslek İle Kadınların İdeal Yaşam Biçimi Çapraz Tablosu

\begin{tabular}{lccccc}
\hline $\begin{array}{l}\text { Size göre kadının } \\
\text { ideal yaşam biçimi } \\
\text { hangisidir }\end{array}$ & Öğretmen & Hemşire & Doktor & Diğer & Toplam \\
\hline $\begin{array}{l}\text { Ev kadınlığ1 ve iş } \\
\text { kadınlığı rollerini } \\
\text { birleştirerek }\end{array}$ & 20 & 16 & 1 & 15 & 52 \\
$\begin{array}{l}\text { yürütmek } \\
\text { Mesleki eğitimi }\end{array}$ & $23,8 \%$ & $19,0 \%$ & $1,2 \%$ & $17,9 \%$ & $61,9 \%$ \\
$\begin{array}{l}\text { görüp gerektiğinde } \\
\text { kullanmak }\end{array}$ & 3 & 1 & 0 & 3 & 7 \\
$\begin{array}{l}\text { Iyi bir anne ve ev } \\
\text { kadını olmak }\end{array}$ & $3,6 \%$ & $1,2 \%$ &, $0 \%$ & $3,6 \%$ & $8,3 \%$ \\
$\begin{array}{l}\text { Başarılı bir iş } \\
\text { kadını olmak }\end{array}$ & $2,6 \%$ & $13,1 \%$ & $1,2 \%$ & $4,8 \%$ & $22,6 \%$ \\
Toplam & $2,4 \%$ & $1,2 \%$ & $1,2 \%$ & $2,4 \%$ & $7,1 \%$ \\
& 28 & 29 & 3 & 24 & 84 \\
& $33,3 \%$ & $34,5 \%$ & $3,6 \%$ & $28,6 \%$ & $100,0 \%$ \\
\hline
\end{tabular}

Tablo 4 incelendiğinde kadınlardan 52 kişi $(\% 61,9)$ kadının ideal yaşam biçiminin kadının aile rolleri ile iş rollerini birleştirerek yürütmek olduğunu belirtmektedirler. $\mathrm{Bu}$ görüşü savunanların 20'si $(\% 23,8)$ öğretmenlik ve 16 's1 $(\% 19,0)$ hemşirelik gibi ev kadınlığının bir uzantısı olan meslekleri yürütmektedirler. Kadının yaşam biçimi olarak iyi bir anne ve ev kadınlığı olduğunu söyleyenler ise 19 kişi $(\% 22,6)$ olup bunların $11^{\prime}$ i $(\% 13,1$ ile) nöbetlere ve uzun çalışma saatlerine maruz kalan hemşireler oluşturmaktadır. Mesleğin, analiz bağlamında yaşamı belirleyici olduğunu da unutmamak gerekmektedir. Kişinin, sosyalleşmesini, ideolojisini, kimliğini, rolünü, statüsünü ve prestijini, bir açıdan bakıldığı takdir de meslek inşa etmektedir (Seçer, 2007: 215-248). "Başarılı Bir Kadın İle Başarılı Bir Erkek Aynı Statülerde Yer Bulabilir Mi” ile "Türkiye Şartlarında Bir Kadının Kolay Yükselme Şansı Bulduğu Sektör”" değişkenleri arasındaki ilişki incelediğinde iş şartlarında başarılı bir kadın ve aynı başarıdaki bir erkeğin aynı statüde yer bulma duruma en yüksek oran 45 kişi tarafından \%53,6 ile hayır cevabı verilmiş ve bu oranın 26 kişi ile \%31,0'1 Türkiye şartlarında kadının kolay yükselebileceği alan olarak reklamcılığ 1 görürken 7 kişi ile \%8,3'de pazarlamada yükselebileceğini söylemektedir. Başarılı bir kadın ile başarılı bir erkeğin aynı statüde yer bulması durumuna en çok cevaplanan ikinci şık ise 32 bayan ve \%38,1 ile evet cevabıdır. Aynı şekilde bu oranda da kadınların Türkiye şartlarında kolay yükselme şansı bulacağı alan olarak reklamcılık ve pazarlama sektörleri gösterilmiştir. İş şartların başarılı kadın olma niteliğine baktıktan sonra kadınların çalışma şartları ile erkeğin çalışma şartları arasında yaptığımız analizde ise kadınlar çalışma şartlarının erkeklere göre düzenlenmiş midir sorusuna yönelttikleri cevaplara baktığımız da en çok işaretlenen şık \%40,5 (34 kişi) ile kısmen katıliyorum olup \%29,8 (25 kişi) de bu soruya katılıyorum cevabını vermişlerdir. Aynı zamanda katılıyorum fikrine paralel olarak kadınların \%29,8'nin (25 kişi) kadınların çalışma şartlarının erkeklere göre düzenlenmemiş olduğunu belirterek katılmıyorum şıkkını işaretlemişlerdir. Çalışma şartları erkeklere göre düzenlenmiştir sorusunu kadınların çalışmasına yönelik yasaların yeterli olup olmamasına göre açtığımızda ise en çok işaretlenen şıkkın 66 kişi $(78,6)$ ile çalışma şartlarının yetersiz olması olup buna çalışma şartlarının kısmen erkeklere göre düzenlendiğini belirtenler 24'ü $(\% 28,6)$ çalışan kadınlara yönelik yasaları yetersiz bulmaktadır. Kadınların çalışması ile kariyer ilişkisini analiz ettiğimiz bu kısımda ise kadınların \%70,2'sinin (59 kişi ile) kariyer ile 
aile rolleri arasında uyumsuzluk olması durumunda tercihlerinin aileleri olacağını söylemektedirler. Bunların \%33,3'ü (28 kişi ile) kadının çalışmasının iyi bir anne ve eş olmasını kısmen engellediğini belirtirken \%31,0'da (26 kişi ile) kadının çalışmasının iyi bir anne ve eş olmasını engelleyemeyeceğini kadının işine de evine de bakabileceğini belirtmektedir. Elde ettiğimiz verilerden hareketle kadının çalışmasının iyi bir anne ve eş olmasının üzerine kısmen etkileri olsa bile tam anlamiyla engel olmadığını ve işleri ile aileleri arasında ciddi bir uyumsuzluk durumunda işlerini bırakıp ailelilerine yöneleceklerini söyleyebiliriz. $\mathrm{Bu}$ analizi destekler nitelikte yaptı̆̆ımız çalışma ve ilk tercih arasındaki sonuçlar ise şöyle ifade edilebilir: kadınların kadının çalışmasının iyi bir anne ve eş olmasını engeller mi sorusuna en yüksek oranda \%47,6 ile (40 kişi) hayır cevabını vermiș ve bunların \%33,3'üne (28 kişi) göre de bir kadın için ilk sırada mutluluk, \%10,7'sine (9 kişi) göre ise ilk sırada çocuk gelmektedir. Bunu takiben en yüksek oranda \%40,5 ile (34) kadının çalışmasının kısmen de olsa iyi bir anne ve eş olmasını engellediği söylenilmektedir. Bu oranın \%21,4’ü (18 kişi) için ilk sırada çocuk gelirken \%19,0’1 (19 kişi) için ise ilk sırada mutluluk gelmektedir. $\mathrm{Bu}$ verilerden hareketle kadınların çoğunluğunun çalışma hayatının kadının iyi bir anne ve eş olmasına bir engellilik teşkil etmediğini uğraşlarının var olması gerektiğini ancak önceliklerinin manevi olarak benimsedikleri mutlulukları ve çocukları olduğunu söyleyebiliriz. Çünkü çocukların dış dünya ile ilişkileri, ahlaki yargıların temellenmesine kaynaklık etmektedir (Çam vd., 2012: 1221).

\section{3. Çalışan Kadın ve İş-Aile Bulguları}

Kentleşmenin artması, bilginin kontrol edilemez ve hızlı bir biçimde yayılması, eğitim ve ulaşım imkânlarının gelişmesi ve toplumsal bilinçte yaşanan değişim ve ilerlemeler, kadınların daha fazla sayıda farklı sektörlerde yer bulmalarına sebep olmuştur. Kadınların sektörel hayatta yer bulmasının ise sonuç açısından aile kavramı ile yaşayacağ bazı problemlerin ortaya çıkmasına öncülük etmiştir. Aile ve iş hayatının, çeşitli sebeplerden dolayı zaman zaman karşı karşıya gelmesi, kadını bir açıdan ciddi bir problemle başbaşa bırakmıştır (Tatlı ve Koç, 2017: 146). İşte aşağıdaki tablo, iş hayatında yer bulan kadınların "ev" ile kavramsal karşılaşmalarında ne düşündüklerine yönelik bir analiz içermektedir.

Tablo 5. Meslek ile İş Yerindeyken Aklınızın Evde Kalmasını Ne Siklıkta Yaşıyorsunuz Çapraz Tablosu

\begin{tabular}{ccccc}
\hline \multirow{2}{*}{ Meslek } & \multicolumn{4}{c}{ İş yerindeyken aklınızın evde kalmasını ne sıklıta } \\
& Hiç & Çok & $\begin{array}{c}\text { yaşıyorsunuz? } \\
\text { Arada Bir }\end{array}$ & Toplam \\
\hline \multirow{2}{*}{ Öğretmen } & 6 & 6 & 16 & 28 \\
& $7,1 \%$ & $7,1 \%$ & $19,1 \%$ & $33,3 \%$ \\
Hemşire & 1 & 17 & 11 & 29 \\
& $1,2 \%$ & $20,2 \%$ & $13,1 \%$ & $34,5 \%$ \\
Doktor & 0 & 1 & 2 & 3 \\
&, $0 \%$ & $1,2 \%$ & $2,4 \%$ & $3,6 \%$ \\
Diğer & 2 & 11 & 11 & 24 \\
& $2,4 \%$ & $13,1 \%$ & $13,1 \%$ & $28,6 \%$ \\
Toplam & 9 & 35 & 40 & 84 \\
& $10,7 \%$ & $41,7 \%$ & $46,4 \%$ & $100,0 \%$ \\
\hline
\end{tabular}

Tablo 5 incelendiğinde çalışan kadınların iş yerinde iken akıllarının evlerinde kalmasını durumunu yönelik soruya 40 kișinin $(\% 46,4)$ arada bir akıllarının evlerinde olduğunu ve buna çok yakın diğer oran ise 35 kişinin $(\% 41,7)$ bu durumu çok sık yaşadıklarını dile getirmişlerdir. Bunu mesleklere göre dağılımına baktığımızda ise bütün çalışan kadınlarda bu kaygının söz konusu olduğunu fakat en çok hemşirelerin bu durumu yaşadığını söyleyebiliriz. Yine yaptığımız başka bir çapraz tablo analizinde ise çalışan kadınların çalışmalarının aile hayatları üzerinde ki olumlu etkileri olarak en yüksek oranda \%38,1 ile ekonomik destek olarak görüp bunun mesleğe göre dağılımında $\% 15,5^{\prime}$ ini hemşireler, $\% 11,9^{\prime}$ unu diğer, \% 9,5' ini öğretmenler ve \%1,2'sini doktorlar oluşturduğu görülmüştür. Çalışmanın aile üzerinde ki diğer olumlu etkisi ise \%21,4 ile düzenli ve programlı bir hayat sürdürmesidir. $\mathrm{Bu}$ oranın mesleğe göre dağılımına baktığımız da çoğunluğunu öğretmenler oluşturmaktadır. Tersi bir durum analizinde ise kadının çalışmasının aile üzerinde bıraktığı olumsuz etkinin 61 bayan $(\% 72,6)$ ile aileye yeteri kadar zaman ayıramama durumundan kaynaklandığını görüyoruz. Bunu mesleğe göre dağılımına baktığımızda ise bu oranın 21 kişisini $(\% 25,0)$ öğretmenler, 20 'sini $(\% 23,8)$ hemşireler, 17 kişiyi $(\% 20,2)$ diğer ve 3 kişiyi ise $(\% 3,6)$ doktorlar oluşturmaktadır. Bunu takip eden diğer olumsuz etkiler de 7 kişi $(\% 10,7)$ "çocuğunun sorunları ile ilgilenememe"; 5 kişi (\%6) "aile ve iş hayatını uyumlaştıramam" ve bunların "hepsini" ise 9 kişi $(\% 10,7)$ tercih etmiştir. Yaptığımız karşılaştırmalı analizden çıkan sonuç, kadınların özellikle sektörel hayata dâhil olduktan sonra çeşitli problemlerle karşılaştıkları ama bu problemlerin en önemlisinin aile olduğudur. Çünkü kadının, eş ve annelik rolü ailenin bütününde yer aldığı için, çalışma hayatı (Kocacık ve Gökkaya, 2005: 212), ailenin geniş zamanını alan bu rolleri ortadan kaldırmaya başlamıştır. Bu sebepten dolayı çalışan kadınları aile olgusu ile yaşadığı başat sorun, aileye zaman ayıramamadır (Susam, 2003). Durum pratik bağlamda bu şekilde analiz edilse dahi, olumlu seyreden gelişmeler de gün yüzüne çıkmaya devam etmektedir. Aile konusunda önemli ve çeşitli sorunlar yaşayan kadının, çalışma hayatı ile aile hayatının karar mekanizmasına ortak olması da pozitif bir veri olarak kabul edilebilir. Özellikle doğum yeri bölgesi ile karşılaştırmalı çapraz tablo analizi yaptığımız aile içi kararlarda etkili olup olmama analizi, bu teorimizi doğrular niteliktedir. Yaptığımız analizde çalışan kadınların büyük bir bölümü \%91,7 oranında aile içinde ki kararı almada eşlerine danışılarak ortak karalar aldıklarını ifade etmişlerdir. Bu oranın \%36,9'unu 31 çalışan bayan ile Doğu Anadolu bölgesindekiler oluştururken onu takip eden en yüksek diğer oranlarda ise \%13,1'ini 11 çalışan bayan ile iç Anadolu bölgesi, \%11,9'u 10 çalışan bayan ile Ege bölgesi ve \%10,7'sini 9 çalışan bayan ile Akdeniz bölgesi oluşturmaktadır. Karaları eşim verir cevabını verenler ise çok az olup \%3,6'lık ile 3 çalışan bayan oluşturmaktadır. Burada doğu toplumunda ikinci planda tutulan kadının çalışma hayatına girmesiyle artık emeğinin karşılığını ücret olarak almasıyla birlikte aile içindeki karaları almada söz sahibi olduğunu söyleyebiliriz. Kadının aile içinde söz sahibi olmasından ziyade alınan kararlarda ortaklık göstermesi önemli ve ilerlemeci bir pratiktir. Lakin tüm bunlara rağmen kadınlara yönelik alınan kararların yeterli olmadığı aşikârdır (Küçük, 2015: 4; Tatlı ve Koç, 2017: 154). Bu bağlamda yaptığımız şu analiz, ifade ettiklerimiz desteklemektedir. Anayasaya Eklenen Yeni Aile Paketi Hakkında Bilginiz Var Mı ve Çalışan Kadınlara Yönelik Yasaları Yeterli Buluyor Musunuz değişkenlerini analiz ettiğimiz çapraz tablo analizinde kadınların çalışan kadınlara yönelik yasaları 
yeterli buluyor musunuz sorusuna 65 kişi $(\% 77,4)$ yetersiz bulduğunu belirtmiştir. Bunu anayasaya eklenen yeni aile paketi hakkında bilgilerinin olup olmamasına göre açtığımızda 24 kişi $(\% 28,6)$ kısmen bilgisi olduğunu, 19 kişi $(\% 22,6)$ evet diyerek bilgisinin olduğunu ve 19 kiși $(\% 22,6)$ hayır diyerek bilgisinin olmadığını belirtmektedir. Bulgulardan hareketle çalışan kadınların büyük çoğunluğunun yeni aile paketi hakkında az çok bilgisinin olduğu ve bunları yetersiz bulduklarını söyleyebiliriz.

\section{Sonuç ve Değerlendirme}

$\mathrm{Bu}$ verilerden hareketle kadınların çalışma hayatında istihdamlarını artırmak ve iş-aile uyumunu sağlayarak rol çatışmasından kurtulmasını sağlamak için öncelikle toplumdaki zihinsel kodların yeniden şekillendirilmesi sağlanmalıdır. Bireylerin kendileriyle uyumlu eşlerle evlenmesi gerekir ve en önemlisi de yasaların çalışan kadınları göz önünde bulundurarak yeniden düzenlenmesiyle iyileştirebileceğini söyleyebiliriz. Muş ilinde kamu sektöründe çalışan kadınlar üzerinde yaptığımız araştırma sonucunda elde edilen bulguların büyük bir kısmı, teorik beklentilerimizi destekler niteliktedir. Araştırmada çalışan kadın sahip olduğu niteliklerin (meslek, eğitim durumu, yaş, doğum yeri, aylık gelir) hem birbiriyle olan ilişkileri hem de günlük hayatta, iş ve aile hayatında olan ilişkileri çerçevesinde ele alınmıştır.

Yaptığımız araştırma sonucunda genelde şu bulgular elde edinmiştir:

(i) Kadının eğitim durumunun yükselmesi ve çalışma hayatına girmesi çekirdek aile yapısını yaygınlaştırmıştır.

(ii) Kamu da kadınların toplumun onlara yüklediği sorumluluklara göre istihdam etmekte olduklarını ve bu yönelimde de bir kabullenmişlik söz konusu olduğunu söyleyebiliriz.

(iii) Genelde hemşire ve öğretmenlik gibi ev kadınlığının bir uzantısı olan mesleklerde istihdam edilmekte ve bunun toplumun onlara benimsettiği gibi artık bir tercih şeklini almaktadır.

(iv) Kadınlar üslendiği bütün rollere rağmen bir kadının ahtapot gibi olması gerektiğini annelik ve ev kadınlığının yanında iş hayatında var olup, bütün yükümlülükleri yerine getirmesi gerektiği sonucuna varılmıştır.

(v) Kadının ideal yaşam biçimi olarak da ev kadınlığı ile iş kadınlığı rollerinin birleştirerek yürütmek olduğu sonucuna varılmıştır.

(vi) Kadının çalışması aileye ekonomik destek ve sosyal güvence sağlaması nedeniyle olumlu etkilemesinin yanında kadının çalışması aileye yeteri kadar zaman ayıramamasına da neden olmaktadır. Ekonomik özgürlükleri elinde olan çalışan kadınlar aile içerisinde karar almada söz sahibi olup çalışmasının iyi bir anne ve eş olmasını engelleyemeyeceği ikisi arasındaki ciddi bir uyumsuzluk durumunda ailesini seçeceği kanısına varılmıştır.

(vii) Toplumda kadının çalışması tam olarak sindirilmemiş olsa bile bu yönelimde çok yol kat edildiğini söyleyebiliriz. Bunun için iş alanlarının artırılması gerekiyor ve aynı zamanda kadınların çalışmalarına yönelik yasal düzenlemeler yetersizdir.
Sonuç olarak elde ettiğimiz bulgulardan hareketle kadınların çalışma hayatında istihdamlarını artırmak ve iş-aile uyumunu sağlayarak rol çatışmasından kurtulmasını sağlamak için öncelikle toplumdaki zihinsel kodların yeniden şekillendirilmesi sağlanmalıdır. Bireylerin kendileriyle uyumlu eşlerle evlenmesi gerekir ve en önemlisi de yasaların çalışan kadınları göz önünde bulundurarak yeniden düzenlenmesiyle iyileştirebileceğini söyleyebiliriz.

Kamuda çalışan 84 evli kadına yönelttiğimiz çalışan kadının karşılaştığı sorunlara yönelik çözüm önerilerimiz şeklinde ki açık uçlu soruya kadınlar karşılaştıkları sorunlar ve özellikle çalışma ile iş hayatının uyumlaştırılmasına yönelik cevaplar verilmiştir. Bu çözüm önerilerini ise yoğunluğuna göre şöyle siralayabiliriz:

(i) Çalışma şartlarının yeniden düzenlenmesi,

(ii) Çalışma şartlarının iyileştirilmesi,

(iii) Esnek çalışma saatlerinin oluşturulması,

(iv) Kadınlara daha fazla istihdam alanı sağlanması

(v) Cinsiyet ayrımcılığın ortadan kaldırılması ve erkek egemen zihniyetin değiştirilmesi,

(vi) Toplumda ki zihinsel kodların değiştirilmesi ve kadının da çalışabileceği görüşü topluma benimsetilmesi,

(vii) İş-aile uyumunu sağlamak için eşlerin uyumlu ve anlayışlı olması,

(viii) Mobbing (duygusal şiddete), fiziksel ve sözlü şiddete karşı yeteri kadar önlemlerin alınması,

(ix) Daha güvenilir çalışma alanlarının oluşturulması,

(x) Emeklilik yaşının düşürülmesi,

(xi) Kadınlara yönelik doğum sonu, süt vb. izinlerin artırılmas1,

(xii) İşverenlerin çalışan annelere daha ılımlı ve olumlu davranması,

(xiii) Çocuk altı yaşına gelene kadar kadınların yarım gün çalıştırılması,

(xiv) İş yerlerinde çocuk bakımını giderecek kreşlerin yapılmas1,

(xv) Özellikle hemşirelerde nöbetlerin kadınlara yazılmamas1,

(xvi) Yasaların kadınların iş-aile çatışmasının oluşmayacağı şeklinde düzenlenmesi gerekmektedir.

\section{Kaynakça}

Adak, N. (2012). Değişen Toplumda Değişen Aile. Ankara: Siyasal Kitapevi.

Agresti, A. (2002). Categorical data analysis. John Wiley Sons, New York.

Aksoy, A., \& Şahin, M. (2005). Çalışan Kadınların İşyerindeki Sorunları: Erzurum Alışveriş Merkezlerinde Bir Araştırma. Yönetim ve Ekonomi Araştırmalarl Dergisi, 3(4), 282-300.

Alp, A. (2007). Yeni Çalışma Biçimleri ve Değişen Aile Yapısı Bağlamında Çalışan Kadın. Yüksek Lisans Projesi. İzmir: Dokuz Eylül Üniversitesi.

Arık, İ. A. (1992). Psikolojide Bilimsel Yöntem. İstanbul: Çantay Kitabevi.

Aslantürk, Z., \& Amman, M. T. (2001). Sosyoloji. İstanbul: Çamlıca Yayınları. 
Atım, R. (2013). Küreselleşen Çalışma Hayatında Türkiye'de Kadın İstihdamını Artırmaya Yönelik Politikalar. Yüksek Lisans Tezi. Sivas: Cumhuriyet Üniversitesi.

Bakan, İ., \& Büyükbeşe, T. (2004). Çalışanların İş Güvencesi ve Genel İş Davranışları İlişkisi: Bir Alan Çalışması. Erciyes Üniversitesi İktisadi ve İdari Bilimler Fakültesi Dergisi, 23, 35-59.

Barret, M. (1980). Women's Opression Today. London: Verso.

Başaran, Y. K. (2017). Sosyal Bilimlerde Örneklem Kuramı. Akademik Sosyal Araştırmalar Dergisi, (5)47, 480-495.

Bilgin, B. (2012). Çalışma Yaşamında Kadın ve Yasal Düzenlemeler, Türkiye Barolar Birliği Dergisi, 99, 312315.

Bingöl, O. (2014) Toplumsal Cinsiyet Olgusu ve Türkiye'de Kadınlık. KMÜ Sosyal ve Ekonomik Araştırmalar Dergisi, 16(Özel Sayı 1), 108-114.

Bircan, H., Karagöz, Y., \& Kasapoğlu, Y. (2003). Ki-Kare ve Kolmogorov Smirnov Uygunluk Testlerinin Simülasyon ile Elde Edilen Veriler Üzerinde Karşılaştırılması. $C \ddot{U}$ İktisadi ve İdari Bilimler Dergisi, 4(1), 69-79.

Büyüköztürk, Ş. (2014). Sosyal Bilimler Iç̧in Veri Analizi El Kitabı. Ankara: Pegem Yayınları.

Can, İ. (2013a). Ailenin Tarihsel Gelişimi: Dünü Bugünü Yarını. İçinde: Sistematik Aile Sosyolojisi, Mustafa Aydın (edt). (s.65-91). Konya: Çizgi Yayınları.

Can, İ. (2013b). Tarih, Toplum ve Kültür Bağlamında Aile ve Kadın. İçinde: Sistematik Aile Sosyolojisi, Mustafa Aydın (edt). (s.215-248). Konya: Çizgi Yayınları.

Can, İ. (2014). Moderniteden Postmoderniteye Ailenin Ontolojisi Ya Da Modern Çekirdek Aile Çerezleşiyor Mu?. İçinde: Aile Sosyolojisi Yazıları, Mustafa Aydın (edt). (s.51-81). İstanbul: Açılım Yayınları.

Çakınberk, A. K. (2011). İş'te Kadın Olmak. Ankara: Nobel Yayınları.

Çam, Z., Çavdar, D., Seydooğulları, S., \& Çok, F. (2012). Ahlak gelişimine klasik ve yeni kuramsal yaklaşımlar. Kuram ve Uygulamada Ĕ̌itim Bilimleri, 12(2), 1211-1225.

Doruk, N. Ç. (2008). Organizasyonlarda İş-Aile Ve Aile Çatışmasının Bireylerin Performansları Üzerindeki Etkileri Isş ve Yaşam Tatmini Rolü. Yüksek Lisans Tezi. Kayseri: Erciyes Üniversitesi.

Erkal, M. E. (2011). Sosyoloji. İstanbul: Der Yayınları.

Eyce, B. (2000) Tarihten Günümüze Türk Ailesi. Selçuk Üniversitesi Sosyal Bilimler MYO Dergisi, 4, 223-243.

Giddens, A. (2008). Sosyoloji. İstanbul: Kırmızı Yayınlar.

Gökdeniz, İ., \& Merdan, E. (2016) Meslek Seçimi ile İş Tatmini İlişkisi: Bankacılık Sektöründe Bir Uygulama. Aksaray Üniversitesi İktisadi ve İdari Bilimler Fakültesi Dergisi, 8(2), 111-121.
Gültekin, G. (2013). Kamu Hizmet Sektöründe Çalışan Memnuniyeti: Yalova Örneği. Yüksek Lisans Tezi. Yalova: Yalova Üniversitesi.

Gündüz, H. Ç., Tarhan, S., \& Kılıç, Z. (2015) Toplumsal Cinsiyete Dayalı Meslek Seçimlerine Yönelik Tutum Ölçeği Geçerlik ve Güvenirlik Çalışması. Bartın Üniversitesi Eğitim Fakültesi Dergisi, 4(1), 21-33.

Güner, A. (2008). Üniversitede Çalışan Kadınların Kadının Çalışma Yaşamındaki Sorunlarına Yönelik Algıları. Yüksek Lisans Tezi. İstanbul: İstanbul Üniversitesi.

Günindi, Y., \& Giren S. Y. (2011). Aile Kavramının Değişim Süreci ve Okul Öncesi Dönemde Ailenin Önemi. Selçuk Üniversitesi Ahmet Keleşoğlu Eğitim Fakültesi Dergisi. 31, 349-361.

Hıdıroğlu, S. (2006). Sağlık İş Kolunda Çalışan Kadınların Çalışma Yaşamı İle İlgili Sorunların Değerlendirilmesi. Doktora Tezi. İstanbul: İstanbul Üniversitesi.

İnce, M. (2010). Kadın İstihdamı ve Kadın İsgücüne Olan Talep: Türkiye Örneği. Doktora Tezi. Afyonkarahisar: Afyon Kocatepe Üniversitesi.

Kahraman, L. (2014). İranlı Kadınların Toplumsal ve Siyasal Profili. Journal of Sociological Research, 17(2), 72-120.

Kaptan, S. (1981). Bilimsel Araştırma Teknikleri ve İstatistik Yöntemleri. Ankara: Rehber Dağıtım.

Karasar, N. (2005). Bilimsel Araştırma Yöntemleri. Ankara: Nobel Yayın.

Kayadibi, F. (2003). Kadın Eğitiminin Önemi ve Kalkınmadaki Rolü. Istanbul Journal Of Sociological Studies, 28, 19-31.

Kocacık, F., \& Gökkaya, B. (2005). Türkiye'de Çalışan Kadınlar ve Sorunları. C. U. Iktisadi ve İdari Bilimler Fakültesi Dergisi, (6)1, 195-219.

Koyuncu, A. A. (2013) Aile Araştırmaları Metodolojisi: Yaklaşımlar ve Yöntemler. İçinde: Sistematik Aile Sosyolojisi, Mustafa Aydın (edt). (s.41-64). Konya: Çizgi Yayınları.

Küçük, M. (2015). Çalışma Hayatında Kadınlar ve Karşılaştıkları Sorunlar: Bir İşverene Bağlı Olarak Çalışan Emekçi Kadınlara İliş̧in Bir Araştırma. Ekonomi Bilimleri Dergisi, 7(1), 1-17.

Lale, İ. M. (2004). Türk Aile Düzeni ve Aile İçi İlişkiler. Yüksek Lisans Tezi. Sakarya: Sakarya Üniversitesi.

Mocionis, J. J. (2012). Sosyoloji. Vildan Akan (Edt.). İstanbul: Nobel Yayınları.

Orçan, M., \& Kar, M. (2008) Türkiye'de Erken Yaşta Yapılan Evlilikler ve Risk Algısı: Bismil Örneği. Aile ve Toplum, 14(14), 97-111.

Önel, N. (2006). İş-Aile Çatışmasının Çalışan Kadının Aile Içi İlişkileri Üzerindeki Etkileri. Yüksek Lisans Tezi. Sakarya: Sakarya Üniversitesi.

Özdamar, K. (2003). Modern Bilimsel Araştırma Yöntemleri. Eskişehir: Kaan Kitabevi.

Özek, M. (2011). Çalışan Annelerin İş Stresiyle Başa Çıkma Becerisi Ile Tükenmişlik Düzeylerinin Aile 
Değerlendirmesine ve Çocuklarının Davranışlarına Etkileri. Yüksek Lisans Tezi. İzmir: Dokuz Eylül Üniversitesi.

Özen, Y., \& Gül, A. (2007). Sosyal ve Eğitim Bilimleri Araştırmalarında Evren-Örneklem Sorunu. Kazım Karabekir Ĕ̈itim Fakültesi Dergisi, 15, 394-422.

Özer, M., \& Biçerli, K. (2003) Türkiye’de Kadın İş Gücünün Panel Veri Analizi. Anadolu Üniversitesi Sosyal Bilimler Dergisi, 3(1), 55-86.

Seçer, H. Ş. (2007). Mesleki Yaşam Modelinin Oluşturulması ve Mesleki Analizlerde Kullanımı. Doktora Tezi. İzmir: Dokuz Eylül Üniversitesi.

Stahmann, R. F. (2000). Premarital Counselling: A Focus for Family Therapy. Journal of Family Therapy, 22, 104116.

Susam, R. T. (2013). Özel Sektörde Calıșan Kadınların Sorunlarl: Erzurum İli Örneği. Yüksek Lisans Tezi. Erzurum: Atatürk Üniversitesi.

Süzer, F., \& Yıldız, A. (2005). Evlenmek Üzere Olan Çiftlerin Kaygı Durumu ve Danışmanlık Gereksinimi. Zonguldak Să̆lık Yüksekokulu Să̆lık Ĕ̆itim Araştırma Dergisi, 1(2), 24-33.

Şenol, Ş. (2012). Araştırma ve Örnekleme Yöntemleri. Ankara: Nobel Yayıncılik.

Şentürk, F. (2016). Türkiye İçin Bir Aile Sigortası Model Önerisi. Sosyal Güvenlik Uzmanlarl Derneği Sosyal Güvence Dergisi, 5(9), 102-139.

Tarhan, Ö. (2015). Sosyal Bilgiler Öğretmeni Adaylarının Politik Okuryazarlığa İlişkin Görüşleri. Akademik Sosyal Araştırmalar Dergisi, 9, 649-669.

Tatlı, H., \& Koç, B. (2017). Çalışan Kadın Bakış Açısıyla Kadınların İş ve Aile Yaşamında Karşılaştığı Sorunlar Hakkında Bir Uygulama. İktisadiyat, 1(1), 145-170.

Yazıcıoğlu, Y., \& Erdoğan, S. (2004). SPSS Uygulamalı Bilimsel Araştırma Yöntemleri. Ankara: Detay Yayıncılik.

Yıldırım, E., \& Canatan, K. (2011). Aile Sosyolojisi: Dünyada ve Türkiye' de Aile Politikalart. İstanbul: Açılım Kitap.

Y1lmaz, A., Bozkurt, Y., \& İzci, F. (2008). Kamu örgütlerinde çalışan kadın işgörenlerin çalışma yaşamlarında karşılaştıkları sorunlar üzerine bir araştırma. Eskişehir Osmangazi Üniversitesi Sosyal Bilimler Dergisi, 9(2), 89-114.

Yumuş, A. (2009). Kamu Sektöründe Çalışan Kadın İşgücü Profili Üzerine Bir Alan Çalışması. Yüksek Lisans Tezi. Ankara: Gazi Üniversitesi. 